\title{
APPLICATION POSSIBILITY OF ENGINE DRIVERS' BODY SEgMENTS RATIOS IN DESIGNING THE CAB' WORKING ENVIRONMENT IN CROATIA
}

\author{
Mikulčić Matea, Modrić Maja,Sumpor Davor
}

University of Zagreb, Faculty of Transport and Traffic Sciences, Vukelićeva 4, 10000 Zagreb, Croatia

\begin{abstract}
A total of 25 anthropological measures important for the engine driver's cab design were taken from a sample of 51 male engine drivers from all parts of Croatia, out of which 5 and 95 percentiles along with central $90 \%$ were determined. According to scientific findings that body height decreases with age, subjects were divided by age into four groups. Calculated arithmetic mean and harmonic mean of ratios hi/h for individual anthropological measures hi in relation to the standing height $\mathrm{h}$ are the same for all age groups, with minor deviations. The research has been taken whenever it was possible to use body ratios hi/h for the design of driver's cab in new vehicles adapted to the target population of drivers, only by knowing standing height and mass span in the central 90\%. For final conclusions the research should be repeated with a larger sample, taking into account amounts of BMI within each age group because of insufficient and unequal number of respondents in age groups.
\end{abstract}

Keyword: engine drivers, body lengths, ratios, functional dependencies, cab design
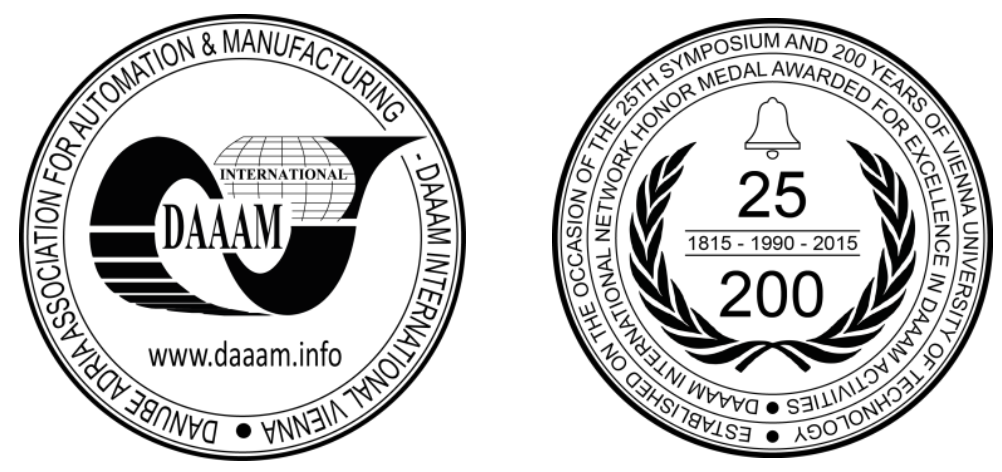

This Publication has to be referred as: Mikulcic, M[atea]; Modric, M[aja] \& Sumpor, D[avor] (2016). Application Possibility of Engine Drivers' Body Segments Ratios in Designing the Cab' Working Environment in Croatia, Proceedings of the 26th DAAAM International Symposium, pp.0842-0848, B. Katalinic (Ed.), Published by DAAAM International, ISBN 978-3-902734-07-5, ISSN 1726-9679, Vienna, Austria

DOI:10.2507/26th.daaam.proceedings. 117 


\section{Introduction}

Factors of working environment from cabin when interacting with anthropological measures of engine drivers can affect the task difficulty, increasing all kinds of workload of drivers (physical, psychological, sensory) during driving, reducing the reliability and safety of the driver.

According to Fuller dynamic TCI model "the ability of drivers - demand tasks" [1], the driver capability is predominantly determined by factors from the group of "human factor", and factors of the "human factor", by selecting the speed of traffic, significantly affects the "tasks demand". The most important influence to the task difficulty (i.e. workload) is placement and accessibility of the frequently used commands to change the speed on the control panel, such as multipurpose controllers for manual serving of the braking module and/or accelerator module (with integrated "dead man" function), which is commonly used in newer tram cabs and newer locomotive cabs in Croatia.

Research of Sumpor et al. from 2012 [2] presents how the physical workload of engine drivers in the static seating working position expressed through the amounts of lumbar moment $M_{l y}=M_{l y}(B M I)$ at the level of vertebra L4/L5 can be intensively affected by the design of the control panel (driver cab), regarding the poor organization of frequently used commands in maximal arm reach. Lumbar moment $M_{l y}$ has functional dependence with amount of $B M I$ index $M_{l y}=M_{l y}(B M I)$ with correlation coefficient $R=0.764$ [2]. A very similar result with a correlation coefficient $R=0.72$ was obtained during research in first part of year 2015 [3].

It is widely known that different people of the same age from different nations have significantly different standing heights at the same time, so that, for example, working space in locomotive cab produced for the Asian market cannot be offered for the Central European market.

Measurements were conducted during the year 2015 on male engine drivers from all parts of Croatia, in the same time with the preparation for writing the undergraduate work [3].

According to Figure 1 [4] the estimate of body height of Croatian men was $\bar{h}=175.8 \mathrm{~cm}$, for the measurements of Croatia which were carried out by Ujević, D. et al. during 2005 and 2006.

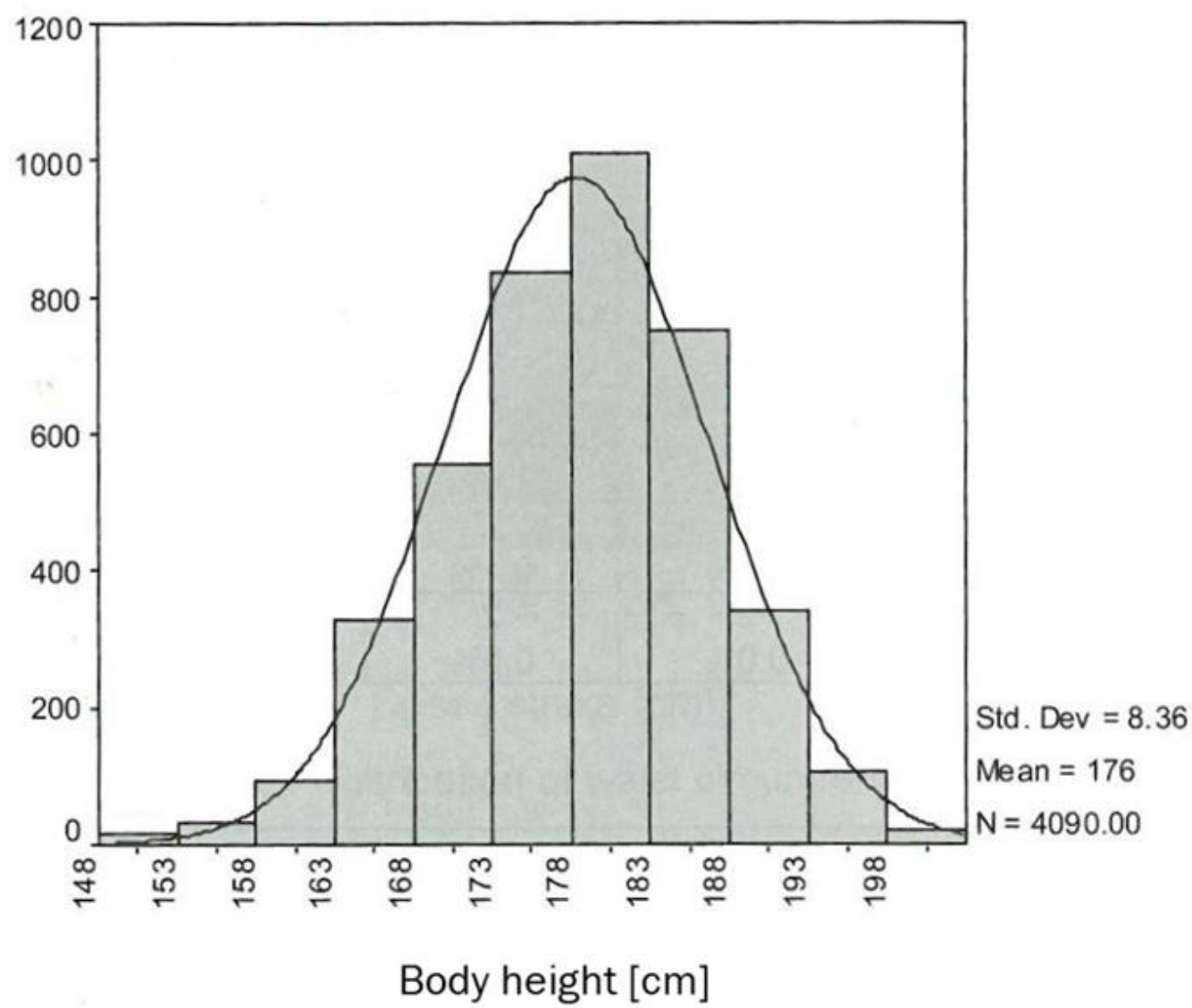

Fig. 1.Distribution of body height in adult men in Croatia Source: Taken from Ujević, D. et al., 2009 [4]

The age of engine drivers significantly affects body height, what is confirmed by the results shown in Table 1, and affects other anthropological measures that are possibly functionally dependent on the body height h. Researchers have wondered: "Is it possible that the age of respondents does not significantly affect body ratios in relation to the current standing body height for anthropological measures important for cabin design?" 


\begin{tabular}{|c|c|c|c|c|c|c|c|c|c|c|c|}
\hline \multirow{3}{*}{$\begin{array}{l}\text { Anthropo- } \\
\text { logical } \\
\text { measures }\end{array}$} & \multirow{3}{*}{ 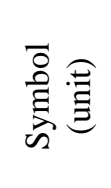 } & \multicolumn{10}{|c|}{ age groups } \\
\hline & & \multicolumn{2}{|c|}{$\begin{array}{c}\text { all sample } \\
(n=51)\end{array}$} & \multicolumn{2}{|c|}{$\begin{array}{l}\text { up to } 29 \text { years } \\
\quad(n=9)\end{array}$} & \multicolumn{2}{|c|}{$\begin{array}{l}\text { from } 30 \text { up } 39 \\
\text { years }(n=13)\end{array}$} & \multicolumn{2}{|c|}{$\begin{array}{l}\text { from } 40 \text { up } 49 \\
\text { years }(n=18)\end{array}$} & \multicolumn{2}{|c|}{$\begin{array}{l}\text { from } 50 \text { up } 59 \\
\text { years }(n=11)\end{array}$} \\
\hline & & M & SD & M & SD & M & SD & M & SD & M & SD \\
\hline Body height & $h(\mathrm{~cm})$ & 178.9 & 5.7 & 177.2 & 6.0 & 180.6 & 6.2 & 178.6 & 6.1 & 178.5 & 4.0 \\
\hline Mass* & $m(k g)$ & 91.9 & 14.1 & 81.4 & 13.9 & 96.5 & 12.9 & 91.2 & 11.3 & 95.6 & 16.5 \\
\hline
\end{tabular}

Table 1. Body height and mass of male engine drivers in Croatia depending on age groups

Fifty one (51) researched engine drivers from Croatia are in the range from 27 to 56 years of age. BMI calculated according to the formula (1) contains two of the most important static anthropological measures standing body height $h$ and mass $m$. BMI is an indicator of possible overweight because of excessive mass $m$ in relation to the standing body height $h$.

$$
B M I=\frac{m}{h^{2}}
$$

Results from Table 2 show that between forty two (42) respondents older than 30 years of age between 72.73 and 92.31 percent are overweight and obese, considering the amount of BMI. Because researched respondents do not have ideal proportions of the body, authors are researching possibility to use their own harmonic method, which is very similar to harmonic analysis by Zederbauer and Muftić. Harmonic analysis by Zederbauer and Muftić is intended for young and healthy adult people of both sexes with the ideal body constitution [5].

\begin{tabular}{lcccccc}
\hline Age groups & $\begin{array}{c}\text { all } \\
\text { sample }\end{array}$ & $\begin{array}{c}\text { up to 29 } \\
\text { years }\end{array}$ & $\begin{array}{c}\text { from 30 up } \\
\text { 39 years }\end{array}$ & $\begin{array}{c}\text { from 40 up } \\
\text { 49 years }\end{array}$ & $\begin{array}{c}\text { from 50 up } \\
59 \text { years }\end{array}$ \\
\hline Number of respondents & $n=51$ & $n=9$ & $n=13$ & $n=18$ & $n=11$ \\
\hline Normal body mass & $n$ & 10 & 4 & 1 & 2 & 3 \\
$B M I=18.5-24.9$ & $\%$ & 19.61 & 44.44 & 7.69 & 11.11 & 27.27 \\
Overweight & $n$ & 24 & 4 & 7 & 10 & 3 \\
$B M I=25-29.9$ & $\%$ & 47.06 & 44.44 & 53.85 & 55.56 & 27.27 \\
Obesity & $n$ & 17 & 1 & 5 & 6 & 5 \\
$B M I \geq 30$ & $\%$ & 33.33 & 11.11 & 38.46 & 33.33 & 45.45 \\
Overweight and & $n$ & 41 & 5 & 12 & 16 & 8 \\
obesity $B M I \geq 25$ & $\%$ & 80.39 & 55.55 & $\mathbf{9 2 . 3 1}$ & $\mathbf{8 8 . 8 9}$ & $\mathbf{7 2 . 7 3}$ \\
\hline
\end{tabular}

Table 2. Number and percentage share of male respondents according to the amount of BMI index depending on age groups

Authors have questioned the hypothesis that the amounts of body ratios, which are calculated as the arithmetic mean $\overline{h_{i} / h}$ or harmonic mean $H$, do not change significantly with the age, despite the change of height and other anthropological measures when comparing the age. Also, in this paper will be researched possible differences in the mean values of body ratios $h_{i} / h$ when used harmonic mean $H$ instead of the arithmetic mean $M$. If it could be chosen during the future researching, the arithmetic mean $\overline{h_{i} / h}$ of body ratios $h_{i} / h$ will be the better option for several reasons.

\section{Measurement results and body ratios}

Figure 2 shows typical anthropological measures in the sagittal plane with labels by Kroemer and Muftic $[5,6]$. Label 19 was added by co-authors. 


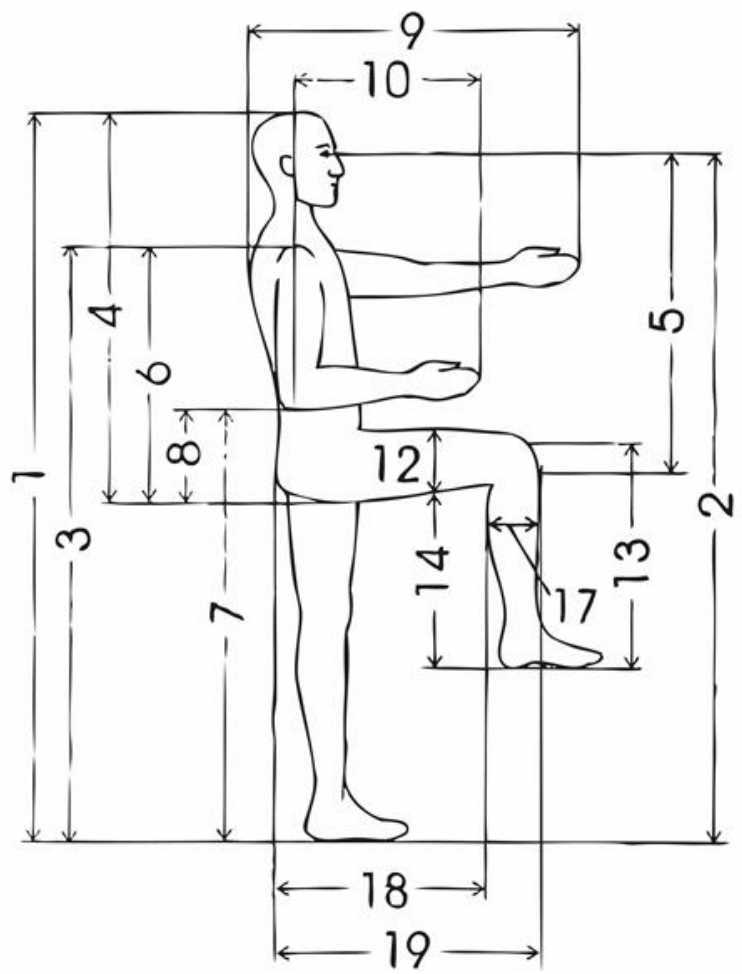

Fig. 2. Showing typical static anthropological measures in the sagittal plane by Kroemer Source: Complemented taken from Muftić, O., Milčić, D. 2001 [4]

Anthropological measures were taken at the same period of time of every measuring day, for the body's segments to the left side of the human body, because 48 of the all 51 respondents are right-handed. The results are rounded to integers in centimetres. If known, the arithmetic mean $M$ and sample standard deviation $S D$, it can be calculated 5 centile and 95 centile for all anthropological measures, according to formulas (2) and (3) taken from Kroemer and Grandjean [6].

$$
\begin{aligned}
& 5,0 \cdot c=M-1,65 \cdot S D \\
& 95,0 \cdot c=M+1,65 \cdot S D
\end{aligned}
$$

According to the instructions provided by Kroemer and Grandjean [6] 5\% of the tallest and 5\% of the shortest individuals of the entire sample of engine drivers should be excluded(in the physical dimension to which the analysis applies). Calculated ranges of engine drivers' anthropological measures in the central $90 \%$ are shown in Table 3. According to Kovač-Striko et al. [7] a sufficiently large sample is $n>30$ from any basic set of the expected mean $M$ and standard deviation $S D$. Due to sorting respondents into four age groups, due to the possible impact of different genotypes and constitutional differences between people, due to possible impacts of different socioeconomic and demographic factors, due to possible impacts of mistakes during the measuring (folds of skin and extensions because of stretching out in joints), as well as due to possible impacts of $B M I$ index amount in a particular age group, it is necessary to increase the sample to the largest possible in the future research.

According to Jurum-Kipke et al. [8] anthropometric variables are polygenetic factors. Phenotype $\left(F_{v}\right)$ is the result of interaction of genotypes $\left(G_{v}\right)$ and many factors of environmental systems $\left(E_{v}\right)$, which is presented with the formula (4).

$F_{v}=E_{v}+G_{v}$

\begin{tabular}{|c|c|c|c|c|c|c|c|c|}
\hline \multirow{3}{*}{ Anthropological measures } & \multirow{3}{*}{$\begin{array}{l}\overline{0} \\
\text { ह } \\
\text { ڤ }\end{array}$} & \multirow{3}{*}{ 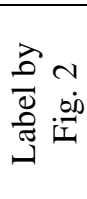 } & \multicolumn{6}{|c|}{ all sample $(n=51)$} \\
\hline & & & M & SD & Perce & entiles & \multicolumn{2}{|c|}{ Ratio } \\
\hline & & & $\begin{array}{c}\mathrm{cm} \\
\left(\mathrm{kg}^{*}\right)\end{array}$ & $\begin{array}{c}\mathrm{cm} \\
\left(\mathrm{kg}^{*}\right)\end{array}$ & $\begin{array}{l}5 \% \\
\mathrm{~cm}\end{array}$ & $\begin{array}{l}95 \% \\
(\mathrm{~kg} *)\end{array}$ & $\overline{h_{i} / h}$ & $\mathrm{H}$ \\
\hline Body height & $h$ & 1 & 178.9 & 5.7 & 169.5 & 188.2 & / & / \\
\hline Mass* & $m$ & & 91.9 & 14.1 & 68.7 & 115.1 & / & I \\
\hline
\end{tabular}


Range of horizontally outstretched arms

Eye height in standing position

Shoulder height in standing position

Elbow height in standing position

Leg lenght

Normal arm reach (from the rear side of the elbow to the middle of a clenched fist)

Maximum arm reach (from the rear side of the akromion to the middle of a clenched fist)

Sitting height to vertex

Eye level in sitting posture

Shoulder level in sitting posture

Elbow level in sitting posture

Knee height in sitting posture

Foot length

Ankle joint height

Horizontal reach of outstretched arm

Length of forearm and hand (from rare side of the elbow to the tip of the longest finger)

Arm length (from akromion to the tip of the longest finger)

Hand length

Below knee height in sitting posture

Bi-acromial range (shoulder width)

$\mathrm{Bi}$-iliocristal range

Length from the back below the knee

Length from the back to the top of the knee

\begin{tabular}{lccccccc}
$h_{11}$ & 11 & 181.0 & 7.3 & 169.0 & 193.1 & 1.01 & 1.01 \\
$h_{2}$ & 2 & 167.9 & 5.4 & 159.1 & 176.8 & 0.94 & 0.94 \\
$h_{3}$ & 3 & 147.1 & 6.2 & 136.9 & 157.3 & 0.82 & 0.82 \\
$h_{7}$ & 7 & 111.3 & 4.6 & 103.7 & 118.8 & 0.62 & 0.62 \\
$h_{n}$ & & 99.3 & 4.6 & 91.7 & 107.0 & 0.56 & $\mathbf{0 . 5 5}$ \\
$h_{n d r}$ & & 35.5 & 2.0 & 32.2 & 38.8 & 0.20 & 0.20 \\
& & & & & & & \\
$h_{m d r}$ & & 64.7 & 3.7 & 58.6 & 70.9 & 0.36 & 0.36 \\
$h_{4}$ & 4 & 90.6 & 3.4 & 85.0 & 96.3 & 0.51 & 0.51 \\
$h_{5}$ & 5 & 80.1 & 3.2 & 74.8 & 85.4 & 0.45 & 0.45 \\
$h_{6}$ & 6 & 61.2 & 2.8 & 56.5 & 65.8 & 0.34 & 0.34 \\
$h_{8}$ & 8 & 25.0 & 3.5 & 19.2 & 30.7 & 0.14 & 0.14 \\
$h_{13}$ & 13 & 54.5 & 2.2 & 50.9 & 58.0 & 0.30 & 0.30 \\
$h_{s d}$ & & 26.4 & 1.2 & 24.3 & 28.4 & 0.15 & 0.15 \\
$h_{s v}$ & & 9.3 & 0.9 & 7.7 & 10.8 & 0.08 & $\mathbf{0 . 0 7}$ \\
$h_{h d r}$ & 9 & 77.1 & 4.8 & 69.1 & 85.1 & 0.43 & 0.43 \\
& & & & & & & \\
$h_{10}$ & 10 & 48.2 & 1.9 & 45.1 & 51.3 & 0.27 & 0.27 \\
& & & & & & & \\
$h_{r}$ & & 77.6 & 3.4 & 71.9 & 83.2 & 0.43 & 0.43 \\
$h_{\check{s}}$ & & 20.0 & 1.1 & 18.2 & 21.8 & 0.11 & 0.11 \\
$h_{14}$ & 14 & 44.5 & 1.8 & 41.5 & 47.4 & 0.25 & 0.25 \\
$h_{\check{s} r}$ & 15 & 40.3 & 2.5 & 36.2 & 44.5 & 0.23 & $\mathbf{0 . 2 2}$ \\
$h_{\check{s} b}$ & & 30.2 & 3.2 & 24.9 & 35.6 & 0.17 & 0.17 \\
$h_{18}$ & 18 & 54.6 & 3.1 & 49.5 & 59.8 & 0.31 & $\mathbf{0 . 3 0}$ \\
$h_{19}$ & 19 & 64.5 & 3.4 & 58.9 & 70.1 & 0.36 & 0.36 \\
\hline
\end{tabular}

Source: 2015 authors' measurement results

Table 3. Engine drivers' body segments ratios and anthropological measures in all sample

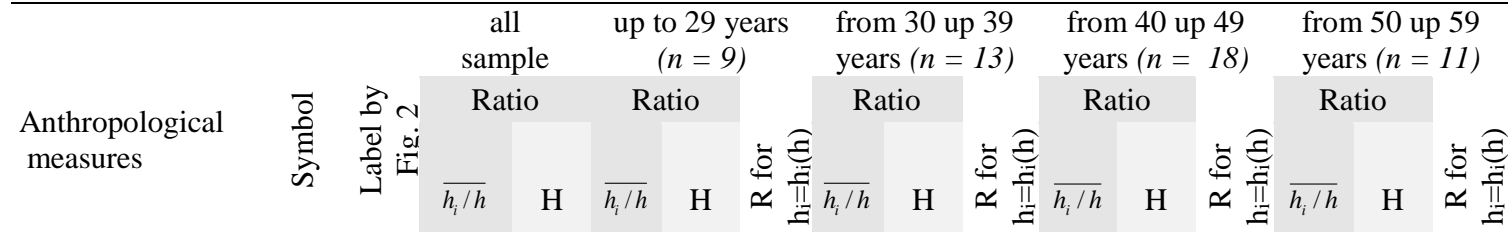

\begin{tabular}{|c|c|c|c|c|c|c|c|c|c|c|c|c|c|c|c|c|}
\hline $\begin{array}{l}\text { Range of } \\
\text { horizontally } \\
\text { outstretched arms }\end{array}$ & $h_{11}$ & 11 & 1.01 & 1.01 & 1.01 & 1.01 & 0.59 & 1.01 & 1.01 & 0.63 & 1.02 & 1.02 & 0.82 & 1.01 & 1.01 & 0.45 \\
\hline $\begin{array}{l}\text { Eye height in } \\
\text { standing position }\end{array}$ & $h_{2}$ & 2 & 0.94 & 0.94 & 0.94 & 0.94 & 0.98 & 0.93 & 0.93 & 0.97 & 0.94 & 0.94 & 0.92 & 0.94 & 0.94 & 0.86 \\
\hline $\begin{array}{l}\text { Shoulder height } \\
\text { in standing } \\
\text { position }\end{array}$ & $h_{3}$ & 3 & 0.82 & 0.82 & 0.82 & 0.82 & 0.85 & 0.82 & 0.82 & 0.97 & 0.82 & 0.82 & 0.58 & 0.82 & 0.82 & 0.73 \\
\hline $\begin{array}{l}\text { Elbow height in } \\
\text { standing position }\end{array}$ & $h_{7}$ & 7 & 0.62 & 0.62 & 0.63 & 0.63 & 0.92 & 0.62 & 0.62 & 0.88 & 0.62 & 0.62 & 0.79 & 0.62 & 0.62 & 0.57 \\
\hline Leg lenght & $h_{n}$ & & 0.56 & 0.55 & 0.55 & 0.55 & 0.77 & 0.55 & 0.55 & 0.72 & 0.57 & 0.56 & 0.81 & 0.55 & 0.55 & 0.93 \\
\hline $\begin{array}{l}\text { Normal arm } \\
\text { reach }\end{array}$ & $h_{n d r}$ & & 0.20 & 0.20 & 0.20 & 0.20 & 0.72 & 0.20 & 0.20 & 0.56 & 0.20 & 0.20 & 0.80 & 0.19 & 0.19 & 0.57 \\
\hline $\begin{array}{l}\text { Maximum arm } \\
\text { reach }\end{array}$ & $h_{m d r}$ & & 0.36 & 0.36 & 0.36 & 0.36 & 0.54 & 0.36 & 0.36 & 0.75 & 0.36 & 0.36 & 0.78 & 0.36 & 0.36 & 0.53 \\
\hline $\begin{array}{l}\text { Sitting height to } \\
\text { vertex }\end{array}$ & $h_{4}$ & 4 & 0.51 & 0.51 & 0.51 & 0.51 & 0.88 & 0.51 & 0.51 & 0.75 & 0.50 & 0.50 & 0.81 & 0.51 & 0.51 & 0.15 \\
\hline
\end{tabular}




\begin{tabular}{|c|c|c|c|c|c|c|c|c|c|c|c|c|c|c|c|c|}
\hline $\begin{array}{l}\text { Eye level in } \\
\text { sitting posture }\end{array}$ & $h_{5}$ & 5 & 0.45 & 0.45 & 0.45 & 0.45 & 0.79 & 0.44 & 0.44 & 0.61 & 0.45 & 0.45 & 0.74 & 0.45 & 0.45 & 0.06 \\
\hline $\begin{array}{l}\text { Shoulder level in } \\
\text { sitting posture }\end{array}$ & $h_{6}$ & 6 & 0.34 & 0.34 & 0.34 & 0.34 & 0.77 & 0.34 & 0.34 & 0.48 & 0.34 & 0.34 & 0.52 & 0.35 & 0.35 & 0.01 \\
\hline $\begin{array}{l}\text { Elbow level in } \\
\text { sitting posture }\end{array}$ & $h_{8}$ & 8 & 0.14 & 0.14 & 0.14 & 0.14 & 0.59 & 0.14 & 0.13 & 0.19 & 0.14 & 0.14 & 0.07 & 0.14 & 0.14 & 0.48 \\
\hline $\begin{array}{l}\text { Knee height in } \\
\text { sitting posture }\end{array}$ & $h_{13}$ & 13 & 0.30 & 0.30 & 0.30 & 0.30 & 0.82 & 0.31 & 0.31 & 0.80 & 0.30 & 0.30 & 0.85 & 0.30 & 0.30 & 0.82 \\
\hline Foot length & $h_{s d}$ & & 0.15 & 0.15 & 0.15 & 0.15 & 0.82 & 0.15 & 0.15 & 0.71 & 0.15 & 0.15 & 0.71 & 0.15 & 0.15 & 0.48 \\
\hline $\begin{array}{l}\text { Ankle joint } \\
\text { height }\end{array}$ & $h_{s v}$ & & 0.08 & 0.07 & 0.09 & 0.08 & 0.07 & 0.07 & 0.07 & 0.51 & 0.07 & 0.07 & 0.47 & 0.07 & 0.07 & 0.64 \\
\hline $\begin{array}{l}\text { Horizontal reach } \\
\text { of outstretched } \\
\text { arm }\end{array}$ & $h_{h d r}$ & 9 & 0.43 & 0.43 & 0.43 & 0.43 & 0.82 & 0.43 & 0.43 & 0.58 & 0.43 & 0.43 & 0.42 & 0.43 & 0.43 & 0.03 \\
\hline $\begin{array}{l}\text { Length of } \\
\text { forearm and hand }\end{array}$ & $h_{10}$ & 10 & 0.27 & 0.27 & 0.27 & 0.27 & 0.92 & 0.27 & 0.27 & 0.63 & 0.27 & 0.27 & 0.65 & 0.27 & 0.27 & 0.40 \\
\hline Arm length & $h_{r}$ & & 0.43 & 0.43 & 0.43 & 0.43 & 0.75 & 0.44 & 0.44 & 0.86 & 0.43 & 0.43 & 0.77 & 0.43 & 0.43 & 0.56 \\
\hline Hand length & $h_{\check{s}}$ & & 0.11 & 0.11 & 0.11 & 0.11 & 0.70 & 0.11 & 0.11 & 0.75 & 0.11 & 0.11 & 0.62 & 0.11 & 0.11 & 0.35 \\
\hline $\begin{array}{l}\text { Below knee } \\
\text { height in sitting } \\
\text { posture }\end{array}$ & $h_{14}$ & 14 & 0.25 & 0.25 & 0.25 & 0.25 & 0.69 & 0.25 & 0.25 & 0.78 & 0.25 & 0.25 & 0.71 & 0.25 & 0.25 & 0.70 \\
\hline $\begin{array}{l}\text { Bi-acromial } \\
\text { range }\end{array}$ & $h_{s r}$ & 15 & 0.23 & 0.22 & 0.22 & 0.22 & 0.25 & 0.22 & 0.22 & 0.10 & 0.23 & 0.23 & 0.45 & 0.23 & 0.23 & 0.00 \\
\hline $\begin{array}{l}\text { Bi-iliocristal } \\
\text { range }\end{array}$ & $h_{\check{s} b}$ & & 0.17 & 0.17 & 0.16 & 0.16 & 0.07 & 0.17 & 0.17 & 0.24 & 0.17 & 0.17 & 0.12 & 0.18 & 0.18 & 0.21 \\
\hline $\begin{array}{l}\text { Length from the } \\
\text { back below the } \\
\text { knee }\end{array}$ & $h_{18}$ & 18 & 0.31 & 0.30 & 0.31 & 0.31 & 0.54 & 0.30 & 0.30 & 0.78 & 0.30 & 0.30 & 0.17 & 0.31 & 0.31 & 0.39 \\
\hline $\begin{array}{l}\text { Length from the } \\
\text { back to the top of } \\
\text { the knee }\end{array}$ & $h_{19}$ & 19 & 0.36 & 0.36 & 0.36 & 0.36 & 0.61 & 0.36 & 0.36 & 0.85 & 0.36 & 0.36 & 0.30 & 0.36 & 0.36 & 0.04 \\
\hline
\end{tabular}

Source: 2015 authors' measurement results

Table 4. Engine drivers' body segments ratios depending on age groups

Results from Table 3 and Table 4 show that calculated arithmetic mean $\overline{h_{i} / h}$ and harmonic mean $H$ of ratios $h_{i} / h$ for individual anthropological measures $h_{i}$ in relation to the standing height $h$ are the same for all age groups and for all sample, with minor deviations. The linearity of functional dependencies between anthropological measures $h_{i}$ and standing height $h$ were evaluated using correlation coefficient $R$. A smaller number of functional dependencies of individual anthropological measures $h_{i}$ about standing height $h$ in the last two age groups comprising older respondents and have significantly lesser and very little correlation coefficient $R$, but with unchanged mean values of the ratios $h_{i} / h$ in all age groups. Between all investigated anthropological measures there were the worst and very weak correlations for bi-acromial range and bi-iliocristal range width standing body height in all four age groups. For bi-acromial range amounts of correlation coefficient $R$ in different age groups are between minimum $(R=0.00)$ and maximum $(R=0.45)$, and for bi-iliocristal range amounts of correlation coefficient $R$ in different age groups are between minimum $(R=0.07)$ and maximum $(R=0.24)$. Similar studies with similar results [9] also indicate to very weak correlations for bi-acromial range width standing body height in males $(R=0.42)$, and also very weak correlations for bi-iliocristal range width standing body height in males $(R=0.21)$, but considered for the entire sample without dividing into age groups.

\section{Conclusion}

In this paper were researched 25 anthropological measures, which are the most important ones for designing engine drivers' cabin, seats and control panel adapted to the target population of engine drivers in Croatia. Research results confirm the basis of the hypothesis that it is possible to use body ratios $h / h$ for the design of driver's cab interior in future, only by knowing standing height $h$ range in the central 90\% from random and sufficient sample. Calculated arithmetic mean $\overline{h_{i} / h}$ and harmonic mean $H$ of engine drivers' body segments ratios $h_{i} / h$ for individual anthropological measures $h_{i}$ in relation to the standing height $h$ are the same for all age groups in sample and also for all samples, with minor deviations. The same situation is repeated for all 25 investigated anthropological measures. For the design of the driver's working environment in a new locomotive or railcar cabins adjusted to the targeted population of drivers, the calculated arithmetic mean $\overline{h_{i} / h}$ of ratios $h_{i} / h$ should be used in the future. Using the arithmetic mean $\overline{h_{i} / h}$ of body segments ratios $h_{i} / h$ other anthropological measures $h_{i}$ can be easily and quickly calculated from the standing body height $h$, if known amounts of standing body height $h$ for 5 and 95 percentiles. Mathematically considered, the sample of drivers from this study is sufficient (sample with more than 30 respondents). Because of insufficient and unequal 
number of respondents in four age groups, for the final conclusions and final confirmation of the hypothesis the research should be repeated with a larger sample, taking into account several important reasons: due to possible impact of different genotypes, due to possible impacts of different socioeconomic and demographic factors, due to possible impacts of mistakes during the measuring (folds of skin and possible extension because of stretching out in joints), as well as due to possible impacts of $B M I$ index amount within a particular age group.

\section{Acknowledgments}

We thank all the respondents, male engine drivers from all parts of Croatia, for their patience and kindness during the research for the preparation of this study. Also, special thanks to the representative of the Railroad Engineers Trade Union of Croatiafor Zagreb Mr. Fotović for his patience in coordinating the research.

\section{References}

[1] R. Fuller, Towards a general theory of driver behaviour, Accident Analysis and prevention 37, Issue 3, Elsevier, 2005, ISSN: 0001-4575, pp. 461-472.

[2] D. Sumpor, D. Taboršak, J. Jurum-Kipke, Anthropometric Measures Important for Control Panel Design in Locomotive or Railcar, Technical Gazette, Scientific proffesional journal of technical faculties of the Josip Juraj Strossmayer University of Osijek, Vol.22, No.1, Slavonski Brod, 2015, pp. 1-10, Original Scientific Paper, ISSN: 1330-3651.

[3] M. Mikulčić, Mechanics of Solid Bodies Applied to the Skeleton of Engine Driver, Undergraduate work, University of Zagreb, Faculty of Transport and Traffic Sciences, Zagreb, 2015 (Original: M. Mikulčić, Mehanika krutih tijela primijenjena na skelet strojovođe, Završni rad, Sveučilište u Zagrebu, Fakultet prometnih znanosti, Zagreb, 2015.)

[4] D. Ujević et al., Theoretical Aspects and Application of Croatian Anthropometric System (CAS), University of Zagreb, Faculty of Textile Technology, Zagreb, 2009, ISBN: 978-953-7105-28-0.

[5] O. Muftić, D. Milčić, Ergonomics in Safety, College of Occupational Safety and Health, Iproz, Zagreb, 2001 (Original:O. Muftić, D. Milčić, Ergonomija u sigurnosti,Visoka škola za sigurnost na radu, Iproz, Zagreb, 2001.).

[6] K.H.E. Kroemer, E. Grandjean, Fitting the Task to the Human, A Textbook of Occupational Ergonomics, Fifth Edition, Published by Taylor \& Francis Ltd., London, 1997(K.H.E. Kroemer, E. Grandjean, Prilagođavanje rada čovjeku, Naklada Slap, Jastrebarsko, 2000., ISBN: 953-191-096-0).

[7] E. Kovač-Striko, T. Fratrović, B. Ivanković, Probability and Statistics with Examples from the Traffic Technology,Textbook of the University of Zagreb, Faculty of Transport and Traffic Sciences,Zagreb, 2008, ISBN: 987-953-243-028-8 (Original: E. Kovač-Striko, T. Fratrović, B. Ivanković, Vjerojatnost i statistika s primjerima iz tehnologije prometa, Sveučilišni udžbenik Sveučilišta u Zagrebu, Fakultet prometnih znanosti, Zagreb, 2008., ISBN: 987-953-243-028-8).

[8] J. Jurum-Kipke, S. Baksa, Z. Kavran, Anthropometric Relations of Human Body in the Function of Traffic Environment Analysis, Proceedings of 3rd International Ergonomics Conference "Ergonomics 2007“", June 13th 16th, Stubičke toplice, 2007, pp. 239-247, ISBN: 978-953-98741-4-6.

[9] A. Ozaslan, B. Karadayi, M. O. Kolusayin, A. Kaya, Stature Estimation from Bi-acromial and Bi-iliocristal Measurements, Romanian Journal of Legal Medicine, Romanian Society of Legal Medicine, Vol.19, No.3, Bucharest, 2011, pp. 171-176, ISSN: 1844-8585. 